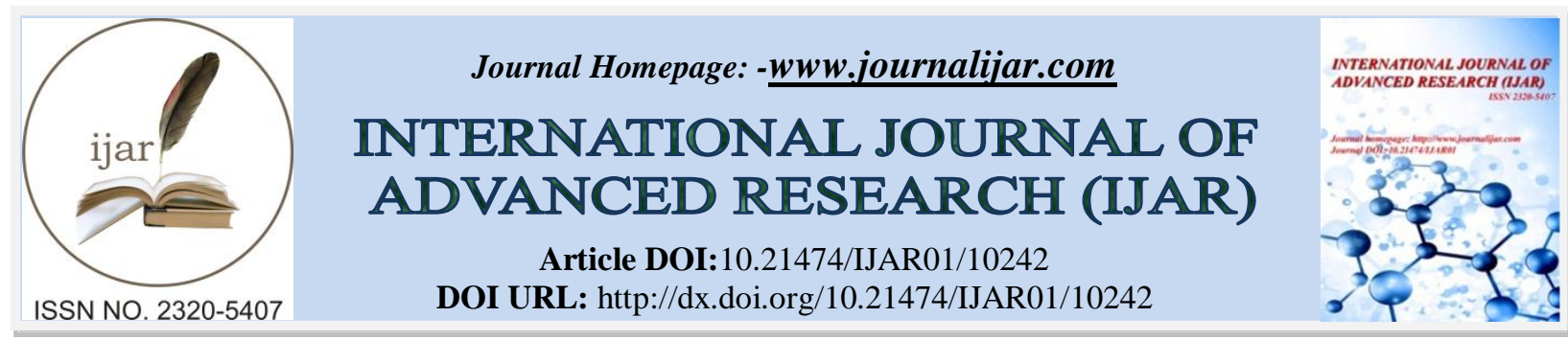

RESEARCH ARTICLE

\title{
DEVELOPMENT OF SUSTAINABLE BROILER PARTNERSHIP PATTERNS IN SUMENEP REGENCY, EAST JAVA PROVINCE
}

\author{
Mufid Dahlan ${ }^{1}$, Z. Fanani' ${ }^{2}$, M. Nur Ihsan ${ }^{2}$ and M. Halim Natsir ${ }^{2}$
}

1. Posgraduate student of Animal Science, Brawijaya University.

2. Lecturer of Animal Science, Brawijaya University.

\section{Manuscript Info}

\section{Manuscript History}

Received: 12 October 2019

Final Accepted: 14 November 2019

Published: December 2019

Key words:-

Sustainable, Broiler, partnership

\begin{abstract}
Breeding development must be started on the paradigm of animal husbandry agribusiness. The pattern of development and development of broilers must consider the value of local wisdom. The purpose of this study is to develop a sustainable broiler partnership pattern in Sumenep Regency, East Java Province. The study was conducted on 1 August 2019 to 30 August 2019 in the Lenteng, Prasional, Guluk Guluk, Pasongsongan and Gandeng Districts. The method used is quantitative. The results showed that maintaining the sustainability of the partnership pattern of broilers must pay attention to aspects of local culture, improve the quality of breeder management skills, increase the capacity of the cage by introducing a semi close house cage.
\end{abstract}

Copy Right, IJAR, 2019,. All rights reserved.

\section{Introduction:-}

Suramadu Bridge also provides opportunities for the development of broiler production at Madura Island; because the second largest broiler market after Jakarta is Surabaya. Broiler supply for Surabaya has been obtained from Gresik, Lamongan, Jombang, Mojokerto and Pasuruan Regencies. The amount of unproductive land on Madura Island is quite wide reaching 70 percent of the total agricultural land. This will be an opportunity for broiler development in Sumenep.

Breeding development must start on the paradigm of animal husbandry agribusiness. Livestock development is realized through the development of upstream agribusiness (breeding industries, animal feed, and veterinary medicines); livestock farming business (on-farm agribusiness); downstream agribusiness (meat, dairy, egg processing and trading industries); and agribusiness support services (financial institutions, transportation, government policies, research and development) simultaneously and consistently (Anonimus, 2000). Therefore this development must be simultaneous from all sub-systems of each stage.

The Overview of the breeding development of animal husbandry in several districts on Madura Island are illustrated as in table 1 as follows :

Table 1:- Comparison of the area, population and number of broiler poultry in 4 districts on the island of Madura.

\begin{tabular}{|l|l|c|c|c|}
\hline No & Region & $\begin{array}{c}\text { Area WIdth } \\
(\mathrm{Km} 2)\end{array}$ & $\begin{array}{c}\text { Population } \\
\text { (Person) }\end{array}$ & Number of Broiler \\
\hline 1 & Bangkalan & $1.001,44$ & 970.894 & 529.800 \\
\hline 2 & Sampang & $1.233,08$ & 968.082 & 300.248 \\
\hline
\end{tabular}

Corresponding Author:- Mufid Dahlan

Address:- Postgraduate Student of Animal Science Brawijaya University. 


\begin{tabular}{|l|l|c|c|c|}
\hline 3 & Pamekasan & 792,24 & 863.004 & 640.000 \\
\hline 4 & Sumenep & $1.998,54$ & 1.081 .204 & 584.250 \\
\hline
\end{tabular}

Source : Sumenep on Numbers (2017).

The table above shows that Sumenep Regency has the largest area and population compared to Bangkalan, Sampang and Pamekasan districts, but on the other hand the number of poultry in disumenep is not in line with the population and area. So that Sumenep Regency is expected to still have great opportunities for the development of poultry, especially broilers. Some things that make this broiler development opportunity is still taking broiler from outside the area. Some large traders serving the Madura region still take broilers from Gresik, Lamongan, Mojokerto, Jombang and Pasuruan. At certain times when there are differences in market prices between East Java and Central Java above Rp. 2000 per kg, chicken delivery can occur from Central Java. Madura Market is very fond of living weight of $2 \mathrm{~kg}$ and above, so that when there is an over supply outside Madura, this size is very suitable to the Madurese's favorite.

In developing the partnership pattern, it cannot be separated from the local customs and culture in the community. The character of the Sumenep community is that they have a high level of adherence to figures in Islam as Latief Wiyata (2003) cited by Mahrus Ali (2010) as saying that cultural specificities appear among others in their obedience, submission, and submission hierarchically to the four main figures in life, all the more so in the praxis of diversity. The four figures are Buppa ', Babbu, Teacher, Ban Rato (father, mother, teacher, and government leader). The influence of the pesantren occupies a strategic position in the community and is greatly influenced and rewarded for its role in the community. The pesantren leadership was posted because of the kyai's charism and the support of the students who were spread throughout the community. (Edi Susanto, 2007). This culture also colors the development of broiler partnership patterns in Sumenep Regency. These four things strongly influence the farmer's decision to partner with broilers, both the problems with whom the farmer will partner, the location of the cage construction, production, access to farm company profile information and the market. This paternalistic feature opened a gap in Madura as an intermediary (broker) which became a liaison between the breeder and the partnership company; because farmers do not dare to step up if there is no information and permission from boarding school figures, even from their students.

\section{Research Purposes:-}

How to develop a sustainable broiler partnership pattern in Sumenep Regency, East Java Province?

\section{Research Result:-}

Test for sustainability alternatives:-

Technological Factors (X1):-

As a material consideration in the factor of sensitive attributes that have dominance and influence the development of sustainable broiler partnerships by looking at the weighting values of each relationship between the sensitive attributes of each factor. Sustainability analysis data for aspects of technology with other sensitive attributes are as follows:

\section{Technology with Social Culture:-}

The value of the relationship between the criteria / aspects of Technology (X1) and Cultural Aspects (X2) is as below:

Table 1:- Weighting value The value of technology sensitive attributes with Socio-cultural sensitivity in the development of broiler partnerships.

\begin{tabular}{|c|l|l|l|l|}
\hline & \multicolumn{1}{|c|}{ SB1 } & \multicolumn{1}{c|}{ SB2 SB3 } & SB4 \\
\hline T1 & 0.703 & 0.896 & 0.650 & 0.896 \\
\hline T2 & 0.404 & 0.309 & 0.592 & 0.610 \\
\hline T3 & 0.640 & 0.695 & 0.775 & 0.529 \\
\hline T4 & -0.097 & 0.890 & 0.956 & 0.890 \\
\hline
\end{tabular}

From the table above it can be seen that the highest influence from the aspect of Technology with cultural variables is: T1 with SB2 amounting to and T1 with SB4 which amount to 0.896. Whereas the lowest influence interaction was shown in T4 with SB1 which was -0.097 . 


\section{Technology with Economics:-}

The value of the relationship between the attributes of technology with economic sensitive attributes based on calculations in appendix 1 , can be seen as Table 2 below.

Table 2:- Weighting value Value of sensitive attributes Technology with economic sensitive attributes in the development of broiler partnerships.

\begin{tabular}{|c|c|c|c|c|c|c|}
\hline & EK1 & EK2 & EK3 & EK4 & EK5 & EK6 \\
\hline T1 & 0.530 & -0.090 & 0.850 & 0.529 & 0.613 & 0.017 \\
\hline T2 & 0.921 & -0.009 & 0.874 & 0.637 & 0.965 & 0.581 \\
\hline T3 & 0.978 & 0.529 & 0.833 & 0.959 & 0.165 & 0.941 \\
\hline T4 & 0.965 & 0.890 & 0.616 & 0.042 & -0.018 & 0.754 \\
\hline
\end{tabular}

From the table above it can be seen that the highest value of the interaction of technological sensitive factors with economic sensitive factor items is: 0.978 , while the lowest value is: -0.090 .

\section{Institutional Technology:-}

The value of the relationship between Technology attributes and Institutional sensitive attributes based on calculations in Appendix 1, can be seen as Table 3 below.

Table 3:- Weighting value Value of sensitive attributes Technology with Institutional sensitive attributes in the development of broiler partnerships.

\begin{tabular}{|c|c|c|c|c|}
\hline & KLB1 & KLB2 & KLB3 & KLB4 \\
\hline T1 & 0.630 & 0.409 & 0.216 & 0.674 \\
\hline T2 & 0.600 & 0.687 & 0.398 & 0.761 \\
\hline T3 & 0.640 & 0.599 & 0.111 & 0.566 \\
\hline T4 & 0.735 & 0.605 & 0.856 & 0.695 \\
\hline
\end{tabular}

From the table above, it can be seen that the highest value for sensitive items with Institutional Technology is 0.761 , namely the interaction between T2 and KLB4 while the lowest value is 0.111 at the value of T2 with KLB3.

According to Suradisastra et al., (2007) the level of participation of farmers in the agricultural development process, through the institutions where they joined, is a quantitative benchmark of institutional performance in channeling farmers' aspirations and achieving the development goals of the livestock sector. In this case, the role of institutions is still very weak, government institutions have not yet reached the bottom level. From this, it is hoped that from the role of government institutions to oversee and regulate partnership cooperation regulations, especially in relation to the stability of DOC stock and the quality of the broiler production facilities that are partnered. The mandate of Act No. 17 of 2019 states that in partnership activities, the government acts as the supervisor of broiler partnership cooperation activities at the district level. The importance of the institution can also be seen from the relationship with the role of the community to contribute to the development of partnerships in Sumenep.

\section{Technology with the Environment:-}

The value of the relationship between the technologies attributes with the environmentally sensitive attributes based on the calculations in appendix 1. It can be seen as Table 5.28 below.

Table 4:- Weighting value Value of sensitive attributes Technology with environmental sensitive attributes in the development of broiler partnerships.

\begin{tabular}{|c|c|c|c|c|}
\hline & LK1 & LK2 & LK3 & LK4 \\
\hline T1 & 0.038 & 0.620 & 0.688 & 0.740 \\
\hline T2 & 0.382 & 0.698 & 0.703 & 0.761 \\
\hline T3 & 0.361 & 0.609 & 0.225 & 0.660 \\
\hline T4 & 0.734 & 0.370 & 0.184 & 0.695 \\
\hline
\end{tabular}


From the table above it can be seen that the highest interaction is 0.741 in the sensitive T1 with K4, while the lowest value is the interaction of T1 sensitive items with LK1 with a value: 0.038 .

\section{Technology with Legal:-}

The value of the relationship between the attributes of technology with legal sensitive attributes based on calculations in appendix 1 can be seen as Table 5 below.

Table 5:- Value weighting Value sensitive attributes Technology with legal sensitive attributes in the development of broiler partnerships.

\begin{tabular}{|l|c|c|}
\hline & HK1 & HK2 \\
\hline T1 & 0.630 & 0.814 \\
\hline T2 & 0.600 & 0.847 \\
\hline T3 & 0.451 & 0.410 \\
\hline T4 & 0.274 & 0.465 \\
\hline
\end{tabular}

From the table above it can be seen that the highest value is at T2 with HK2 which is 0.874 , while the lowest value is 0.274 on sensitive items T4 with HK1.

Socio-Cultural Factors (X2):-

Social Culture with Technology:-

The value of the relationship between Socio-cultural attributes and the sensitive attributes of Technology based on the calculations in appendix 1 can be seen as Table 6 below.

Table 6:- Weighting value Social-sensitive cultural attributes with sensitive attributes Technology in the development of broiler partnerships.

\begin{tabular}{|c|c|c|c|c|}
\hline & T1 & T2 & T3 & T4 \\
\hline SB1 & 0.703 & 0.404 & 0.640 & -0.097 \\
\hline SB2 & 0.896 & 0.309 & 0.695 & 0.890 \\
\hline SB3 & 0.650 & 0.592 & 0.775 & 0.956 \\
\hline SB4 & 0.896 & 0.610 & 0.529 & 0.890 \\
\hline
\end{tabular}

From the table above it can be seen that the highest value is on SB3 with T4 which is 0.956, while the lowest value is - 0.097 on sensitive items SB1 with T4.

\section{Socio-Culture and Economy:-}

The value of the relationship between Socio-Cultural attributes and Economic sensitive (EK) attributes based on calculations in appendix 1 can be seen as Table 6 below.

Table 7:- Weighting value Social-sensitive cultural attributes with Economic sensitive attributes in the development of broiler partnerships.

\begin{tabular}{|c|c|c|c|c|c|c|}
\hline & EK1 & EK2 & EK3 & EK4 & EK5 & EK6 \\
\hline SB1 & 0.996 & 0.110 & 0.548 & 0.652 & 0.330 & 0.486 \\
\hline SB2 & 0.896 & 0.84 & 0.563 & 0.631 & 0.607 & 0.864 \\
\hline SB3 & 0.813 & 0.110 & 0.773 & 0.210 & 0.330 & 0.770 \\
\hline SB4 & 0.873 & 0.426 & 0.770 & 0.101 & 0.706 & 0.443 \\
\hline
\end{tabular}

From the table above it can be seen that the highest value is on SB1 with EK1 which is 0.996, while the lowest value is 0.101 on sensitive items SB4 with EK4.

\section{Social Culture and Environment:-}

The value of the relationship between Socio-Cultural attributes and Environmental sensitive (LK) attributes based on the calculations in appendix 1 can be seen as Table 5.32 below. 
Table 8:- Weighting value Social-sensitive cultural attributes with environmentally sensitive attributes in the development of broiler partnerships.

\begin{tabular}{|c|c|c|c|c|}
\hline & LK1 & LK2 & LK3 & LK4 \\
\hline SB1 & 0.895 & 0.764 & 0.768 & 0.721 \\
\hline SB2 & 0.734 & 0.072 & 0.802 & 0.867 \\
\hline SB3 & 0.111 & 0.138 & 0.227 & 0.107 \\
\hline SB4 & 0.734 & 0.214 & 0.680 & 0.559 \\
\hline
\end{tabular}

From the table above it can be seen that the highest value is on SB1 with LK1 of 0.895, while the lowest value is on sensitive items SB2 with LK2 of 0.072.

\section{Social Culture with Institutional:-}

The value of the relationship between Socio-Cultural attributes and Institutional sensitive attributes is based on calculations in appendix 1 can be seen as Table 5.33 below.

Table 9:- Weighting value Social-sensitive cultural attributes with Institutional sensitive attributes in the development of broiler partnerships.

\begin{tabular}{|c|c|c|c|c|}
\hline & KLB1 & KLB2 & KLB3 & KLB4 \\
\hline SB1 & 0.895 & 0.883 & 0.792 & 0.804 \\
\hline SB2 & 0.734 & 0.783 & 0.104 & 0.202 \\
\hline SB3 & 0.53 & 0.640 & 0.508 & 0.452 \\
\hline SB4 & 0.734 & 0.783 & 0.104 & 0.663 \\
\hline
\end{tabular}

From the table above it can be seen that the highest value is on SB1 with LK1 with 0.895, while the lowest value is on sensitive items SB2 with KLB2 of 0.104.

\section{Social Culture with Legal:-}

The value of the relationship between Socio-Cultural attributes and Legal sensitive attributes based on calculations in Appendix 1 can be seen as Table 10 below.

Table 10:- Weighting value Social-sensitive cultural attributes with sensitive attributes Law in the development of broiler partnerships.

\begin{tabular}{|l|c|c|}
\hline & HK1 & HK2 \\
\hline SB1 & 0.111 & 0.141 \\
\hline SB2 & 0.734 & 0.104 \\
\hline & & \\
\hline SB3 & 0.895 & 0.141 \\
\hline SB4 & 0.734 & 0.577 \\
\hline
\end{tabular}

From the table above it can be seen that the highest value is on SB3 with HK1 which is 0.895 , while the lowest value is on sensitive items SB1 with HK1 of 0.111 .

\section{Economic Factors (X3):-}

\section{Economic Factors with Technology:-}

The value of the relationship between Economic attributes and Technology sensitive attributes based on calculations in Appendix 1 can be seen as Table 11 below.

Table 11:- Weighting value Social-sensitive cultural attributes with Legal sensitive attributes in the development of broiler partnerships.

\begin{tabular}{|c|c|c|c|c|}
\hline & T1 & T2 & T3 & T4 \\
\hline EK1 & 0.530 & 0.921 & 0.988 & 0.965 \\
\hline EK2 & -0.090 & -0.009 & 0.529 & 0.890 \\
\hline EK3 & 0.850 & 0.874 & 0.833 & 0.616 \\
\hline EK4 & 0.529 & 0.637 & 0.959 & 0.042 \\
\hline
\end{tabular}




\begin{tabular}{|l|l|l|l|l|}
\hline EK5 & 0.613 & 0.965 & 0.165 & -0.018 \\
\hline EK6 & 0.017 & 0.581 & 0.941 & 0.759 \\
\hline
\end{tabular}

From the table above it can be seen that the highest value is on EK1 with T3 which is 0.988, while the lowest value is on sensitive items EK21 with T1 of - 0.090 .

\section{Economic Factors with Socio-Culture:-}

The value of the relationship between Socio-cultural attributes and Socio-cultural sensitive attributes is based on calculations in appendix 1 . It can be seen as Table 12 below.

Table 12:- Weighting value Social-sensitive cultural attributes with Legal sensitive attributes in the development of broiler partnerships.

\begin{tabular}{|c|c|c|c|c|}
\hline & SB1 & SB2 & SB3 & SB4 \\
\hline EK1 & 0.996 & 0.896 & 0.813 & 0.873 \\
\hline EK2 & 0.110 & 0.834 & 0.110 & 0.426 \\
\hline EK3 & 0.548 & 0.563 & 0.773 & 0.770 \\
\hline EK4 & 0.665 & 0.631 & 0.210 & 0.101 \\
\hline EK5 & 0.330 & 0.607 & 0.330 & 0.706 \\
\hline EK6 & 0.486 & 0.864 & 0.770 & 0.443 \\
\hline
\end{tabular}

From the table above it can be seen that the highest value is on EK1 with SB1 which is 0.996, while the lowest value is on sensitive items EK4 with SB4 of 0.101.

\section{Economic Factors with Institutional:-}

The value of the relationship between Socio-Cultural attributes and Institutional sensitive attributes based on calculations in appendix 1 can be seen as Table 13 below.Table 13. Weighting value Social-sensitive cultural attributes with Institutional sensitive attributes in the development of broiler partnerships.

\begin{tabular}{|c|c|c|c|c|}
\hline & KLB1 & KLB2 & KLB3 & KLB4 \\
\hline EK1 & 0.503 & 0.731 & 0.510 & 0.896 \\
\hline EK2 & 0.081 & 0.024 & 0.011 & 0.834 \\
\hline EK3 & 0.919 & 0.734 & 0.530 & 0.973 \\
\hline EK4 & 0.141 & 0.767 & 0.916 & 0.834 \\
\hline EK5 & 0.403 & 0.896 & 0.958 & 0.731 \\
\hline EK6 & 0.201 & 0.024 & 0.878 & 0.843 \\
\hline
\end{tabular}

From the table above it can be seen that the highest value is at EK3 with KLB4 which is 0.973, while the lowest value is on sensitive items EK2 with KLB3 of 0.011 .

\section{Economic Factors with the Environment:-}

The value of the relationship between Socio-Cultural attributes and Environmental sensitive attributes is based on calculations in appendix 1 . It can be seen as Table 14 below.

Table 14:- Weighting value Social-sensitive cultural attributes with environmentally sensitive attributes in the development of broiler partnerships.

\begin{tabular}{|c|c|c|c|c|}
\hline & LK1 & LK2 & LK3 & LK4 \\
\hline EK1 & 0.503 & 0.731 & 0.510 & 0.896 \\
\hline EK2 & 0.081 & 0.024 & 0.011 & 0.843 \\
\hline EK3 & 0.919 & 0.734 & 0.530 & 0.973 \\
\hline EK4 & 0.141 & 0.767 & 0.916 & 0.835 \\
\hline EK5 & 0.403 & 0.891 & 0.958 & 0.731 \\
\hline EK6 & 0.201 & 0.024 & 0.878 & 0.843 \\
\hline
\end{tabular}


From the table above it can be seen that the highest value is on EK3 with LK4 which is 0.973, while the lowest value is on EK2 sensitive items with KLB3 of 0.011 .

\section{Economic Factors with Legal:-}

The value of the relationship between Socio-Cultural attributes and Legal sensitive attributes is based on calculations in appendix 1 . It can be seen as Table 15 below.

\begin{tabular}{|l|l|l|}
\hline & HK1 & HK2 \\
\hline EK1 & 0.845 & 0.896 \\
\hline EK2 & 0.855 & 0.458 \\
\hline EK3 & 0.543 & 0.351 \\
\hline EK4 & 0.750 & 0.577 \\
\hline EK5 & 0.828 & 0.814 \\
\hline EK6 & 0.661 & 0.289 \\
\hline
\end{tabular}

From the table above it can be seen that the highest value is at EK3 with HK2 of 0.896, while the lowest value is on EK23 sensitive items with HK2 of 0.351 .

\section{Environmental Factors (X4):-}

Environmental Factors with Economics:-

The value of the relationship between Environmental attributes and Economic sensitive attributes is based on calculations in appendix 1 . It can be seen as Table 16 below.

Table 16:- Weighting value The value of environmentally sensitive attributes with economic sensitive attributes in the development of broiler partnerships.

\begin{tabular}{|l|l|l|l|l|l|l|}
\hline & EK1 & \multicolumn{1}{|c|}{ EK2 } & \multicolumn{1}{c|}{ EK3 } & \multicolumn{1}{c|}{ EK4 } & EK6 \\
\hline LK1 & 0.503 & 0.081 & 0.919 & 0.141 & 0.403 & 0.201 \\
\hline LK2 & 0.731 & 0.024 & 0.734 & 0.767 & 0.896 & 0.024 \\
\hline LK3 & 0.510 & 0.011 & 0.530 & 0.916 & 0.958 & 0.878 \\
\hline LK4 & 0.896 & 0.843 & 0.843 & 0.835 & 0.731 & 0.843 \\
\hline
\end{tabular}

From the table above, it can be seen that the highest value is in LK3 with EK5 which is 0.958, while the lowest value is in LK3 sensitive items with EK 2 of 0.011.

\section{Environmental Factors with Technology:-}

The value of the relationship between Environmental attributes and Environmental sensitive attributes is based on calculations in Appendix 1. It can be seen as Table 17 below.

Table 17:- Weighting value The value of environmentally sensitive attributes Technology sensitive attributes in the development of broiler partnerships.

\begin{tabular}{|c|c|c|c|c|}
\hline & T1 & T2 & T3 & T4 \\
\hline LK1 & 0.038 & 0.382 & 0.362 & 0.734 \\
\hline LK2 & 0.620 & 0.698 & 0.609 & 0.370 \\
\hline LK3 & 0.688 & 0.703 & 0.225 & 0.184 \\
\hline LK4 & 0.740 & 0.761 & 0.660 & 0.695 \\
\hline
\end{tabular}

From the table above it can be seen that the highest value is on LK3 with T1 which is 0.688 , while the lowest value is on LK2 sensitive items with T1 of 0.038 .

\section{Social and Cultural Environment:-}

The value of the relationship between Environmental attributes and Environmental sensitive attributes based on calculations in Appendix 1 can be seen as Table 18 below.

Table 18:- The weighting value is the value of environmentally sensitive attributes with socio-cultural sensitive attributes in the development of a broiler partnership.

\begin{tabular}{|l|l|l|l|l|}
\hline & SB1 & SB2 & SB3 & SB4 \\
\hline
\end{tabular}




\begin{tabular}{|l|l|l|l|l|}
\hline LK1 & 0.895 & -0.073 & 0.111 & -0.073 \\
\hline LK2 & 0.764 & 0.072 & 0.138 & 0.072 \\
\hline LK3 & 0.768 & 0.802 & 0.227 & 0.680 \\
\hline LK4 & 0.721 & 0.867 & 0.107 & 0.559 \\
\hline
\end{tabular}

From the table above it can be seen that the highest value is in LK1 with SB1 which is 0.895 , while the lowest value is in LK1 sensitive items with SB2 of -0.073 .

\section{Institutional Environment:-}

The value of the relationship between Environmental attributes and Institutional sensitive attributes based on calculations in appendix 1 can be seen as Table 19 below.

Table 19:- Weighting value The value of environmentally sensitive attributes with Institutional sensitive attributes in the development of broiler partnerships.

\begin{tabular}{|l|c|c|c|c|}
\hline & KLB1 & KLB2 & KLB3 & KLB4 \\
\hline LK1 & 0.813 & 0.811 & 0.111 & 0.141 \\
\hline LK2 & 0.896 & 0.238 & 0.734 & 0.104 \\
\hline LK3 & 0.503 & 0.081 & 0.111 & 0.141 \\
\hline LK4 & 0.896 & 0.843 & 0.734 & 0.835 \\
\hline
\end{tabular}

From the table above it can be seen that the highest value is in LK1 with SB1 which is 0.895 , while the lowest value is in LK1 sensitive items with SB2 of -0.073 .

\section{Environment with Legal:-}

The value of the relationship between Environmental attributes and Institutional sensitive attributes based on calculations in appendix 1 can be seen as Table 20 below.

Table 20:- Weighting value The value of environmentally sensitive attributes with Institutional sensitive attributes in the development of broiler partnerships.

\begin{tabular}{|l|c|c|}
\hline & HK1 & HK2 \\
\hline LK1 & 0.895 & 0.792 \\
\hline LK2 & 0.340 & 0.104 \\
\hline LK3 & 0.530 & 0.508 \\
\hline LK4 & 0.340 & 0.577 \\
\hline
\end{tabular}

From the table above it can be seen that the highest value is in LK1 with HK1 which is 0.895 , while the lowest value is in LK2 sensitive items with HK2 of 0.104.

\section{Institutional Factors (X5):-}

Institutional with Technology:-

The value of the relationship between Environmental attributes and Institutional sensitive attributes based on calculations in Appendix 1 can be seen as Table 5.43 below.

Table 21:- Weighting value. The value of environmentally sensitive attributes with Institutional sensitive attributes in the development of broiler partnerships.

\begin{tabular}{|c|c|c|c|c|}
\hline & T1 & T2 & T3 & T4 \\
\hline KLB1 & 0.630 & 0.600 & 0.509 & -0.735 \\
\hline KLB2 & 0.409 & 0.687 & 0.599 & 0.605 \\
\hline KLB3 & 0.216 & 0.398 & 0.111 & 0.856 \\
\hline KLB4 & 0.674 & 0.761 & 0.566 & 0.695 \\
\hline
\end{tabular}

From the table above it can be seen that the highest value is at KLB3 with T4 which is 0.856 , while the lowest value is on sensitive items of KLB with T4 of -0.0735 . 


\section{Institutional and Social Culture:-}

The value of the relationship between Environmental attributes and Institutional sensitive attributes based on calculations in Appendix 1 can be seen as Table 22 below.

Table 22:- Weighting value Institutional sensitive attributes with socio-cultural sensitive attributes in the development of broiler partnerships.

From the table above it can be seen that the highest value is at KLB 1 with SB1 which is 0.895 , while the lowest value is on sensitive items KLB 4 with SB2 of -0.804 .

\section{Institutional with Economy:-}

The value of the relationship between Institutional attributes and Economic sensitive attributes is based on calculations in appendix 1 . It can be seen as Table 23 below.

Table 23:- Weighting value Institutional sensitive attributes Economic sensitive attributes in the development of broiler partnerships.

\begin{tabular}{|c|c|c|c|c|}
\hline & SB1 & SB2 & SB3 & SB4 \\
\hline KLB1 & 0.895 & 0.734 & 0.530 & 0.734 \\
\hline KLB2 & 0.883 & 0.783 & 0.640 & 0.783 \\
\hline KLB3 & 0.792 & 0.104 & 0.508 & 0.104 \\
\hline KLB4 & -0.804 & -0.002 & 0.452 & 0.63 \\
\hline
\end{tabular}

From the table above it can be seen that the highest value is in LK1 with SB1 which is 0.895 , while the lowest value is in LK1 sensitive items with SB2 of -0.073 .

Institutional with the Environment:-

The value of the relationship between Institutional attributes and Environmental sensitive attributes is based on

\begin{tabular}{|c|c|c|c|c|}
\hline & LK1 & LK2 & LK3 & LK4 \\
\hline KLB1 & 0.813 & 0.764 & 0.503 & 0.896 \\
\hline KLB2 & 0.811 & 0.072 & 0.081 & 0.843 \\
\hline KLB3 & 0.111 & 0.138 & 0.111 & 0.734 \\
\hline KLB4 & 0.141 & 0.104 & 0.104 & 0.835 \\
\hline
\end{tabular}

calculations in appendix 1 . It can be seen as Table 24 below.

Table 24:- Weighting value Institutional sensitive attribute Environmental sensitive attributes in the development of broiler partnerships.

\begin{tabular}{|c|c|c|c|c|c|c|}
\hline & EK1 & EK2 & EK3 & EK4 & EK5 & EK6 \\
\hline KLB1 & 0.503 & 0.081 & 0.919 & 0.141 & 0.40 & 0.201 \\
\hline KLB2 & 0.731 & 0.024 & 0.734 & 0.767 & 0.90 & 0.024 \\
\hline KLB3 & 0.510 & 0.011 & 0.530 & 0.916 & 0.96 & 0.878 \\
\hline KLB4 & 0.896 & 0.843 & 0.973 & 0.835 & 0.73 & 0.843 \\
\hline
\end{tabular}

From the table above it can be seen that the highest value is in KLB1 with LK4 that is 0.896 while the lowest value is in sensitive items KLB2 with LK2 of 0.072 .

Institutional with Legal:-

The value of the relationship between the Institutional attribute and the sensitive attribute based on the calculation in Appendix 1 can be seen as Table 25 below.

Table 25:- Weighting value Institutional sensitive attributes Legal sensitive attributes in the development of broiler partnerships.

\begin{tabular}{|c|c|c|}
\hline & HK1 & HK2 \\
\hline KLB1 & 0.919 & 0.508 \\
\hline KLB2 & 0.733 & 0.668 \\
\hline KLB3 & 0.944 & 0.916 \\
\hline KLB4 & 0.973 & 0.835 \\
\hline
\end{tabular}


From the table above it can be seen that the highest value is in KLB3 with HK1 which is 0.944 while the lowest value is in sensitive items KLB1 with HK2 of 0.508 .

\section{Conclusion:-}

Based on the formulation of the research problem through proof and discussion above, it can be concluded some suggestions as follows:

1. Maintaining the sustainability of broiler partnership patterns must pay attention to aspects of local culture, improve the quality of breeder management skills and increase the capacity of the cage by introducing the semi close house cage.

2. The sustainability of the broiler partnership in Sumenep Regency is paying attention to:

3. The institutional factor with the highest weight value is 0.5699 ,

4. technology variable sub variable enclosure equipment with weights: 0.6758 ,

5. Socio-cultural variable sub variable tastes of large chicken markets is above $2 \mathrm{~kg}$ with the best weight is 0.8327 .

6. The economic variable sub variable labor has a weight of 0.5981 .

7. Environmental variable sub variable social cultural impact has a good weight that is 0.9537 .

8. The institutional variable sub-variable livestock cooperatives have a weight that is 0.9919 .

9. While the legal variable of the written work contract sub-variable has a good weighting of 1.5206.

\section{Reference:-}

1. Ali, M. 2010. Akomodasi Nilai Nilai Masyarakat Madura Mengenai Penyelesaian Carok Dalam Hukum Pidana. Jurnal Hukum Ius Quia Iustum, 17(1): 85-102.

2. Anonimus. 2000. Pedoman Usaha Kemitraan Pertanian. SK Mentan No 940/Kpts/01210/1997. Lembar InformasiPertanian (LIPTAN) LPTP Jakarta.

3. Suradisastra, K., Basuno, \& Tarigan. 2007. Prosiding kinerja dan prospek pembangunan pertanian Indonesia. Status dan Arah Pengembangan Kelembagaan Petani. Vol 6: 106.

4. Susanto Edi. 2007. Kepemimpinan (Kharismatik) Kyai dalam Perspektif Masyarakat Madura. Jurnal KARSA Vol. XI No. 1 April 2007. 